\title{
Basic FGF Increases Communication between Cells of the Developing Neocortex
}

\author{
B. Nadarajah, ${ }^{1}$ H. Makarenkova, ${ }^{2}$ D. L. Becker, ${ }^{1}$ W. H. Evans, ${ }^{3}$ and J. G. Parnavelas ${ }^{1}$ \\ ${ }^{1}$ Department of Anatomy and Developmental Biology and ${ }^{2 M e d i c a l ~ R e s e a r c h ~ C o u n c i l ~ L a b o r a t o r y ~ o f ~ M o l e c u l a r ~ C e l l ~}$ \\ Biology, University College London, London WC1E 6BT, United Kingdom, and ${ }^{3}$ Department of Medical Biochemistry, \\ University of Wales College of Medicine, Cardiff CF4 4XN, United Kingdom
}

\begin{abstract}
We have found that basic fibroblast growth factor (bFGF), applied to cortical progenitor cells in vitro, produces an increase in the expression of the gap junction protein connexin (Cx) 43 and in the mRNA encoding Cx 43. This effect was evident in both proliferating and nonproliferating cells. The elevated levels of mRNA suggest that bFGF is likely to exert its effect by upregulating the rate of transcription of the Cx 43 gene. We have further shown that the increase in Cx 43 expres-
\end{abstract}

sion is mediated through the receptor tyrosine kinase pathway and is associated with enhanced intercellular dye-coupling mediated by gap junctions. These results suggest that gap junction channels provide a direct conduit for mitogens released in response to bFGF to effectively regulate proliferation during corticogenesis.

Key words: connexin 43; gap junctions; dye-coupling; bFGF; development; neocortex
The complex functions of the cerebral cortex involve interactions between the various neuronal and glial cell types. These cells, which arise from proliferating neuroepithelial cells of the ventricular zone of the developing telencephalon, are generated according to a precise time schedule (Rakic, 1995). The mechanisms leading to the production of the neurons and glia are not well understood, but it is thought that both cell lineage and local environmental factors play important roles in cell phenotype determination (McConnell, 1991). A number of soluble factors present in the proliferative zone of the developing cortex have been shown to regulate the proliferation and differentiation of cortical progenitor cells in vitro. These include growth factors, neurotrophins, extracellular matrix molecules, and neurotransmitters (McKay, 1989; Davis and Temple, 1994; LoTurco et al., 1995). Of the growth factors, basic fibroblast growth factor (bFGF) has been shown to have distinct effects on the proliferation and differentiation of cortical progenitor cells to a particular lineage (Ghosh and Greenberg, 1995; Temple and Qian, 1995; Pappas and Parnavelas, 1997, 1998).

In addition to responding to extracellular diffusible factors, cells in the ventricular zone communicate directly with each other by gap junction-mediated intercellular coupling (LoTurco and Kreigstein, 1991). A gap intercellular communication channel is formed by two hemichannels or connexons contributed by each of the coupled cells. Each hemichannel is composed of six connexin proteins and is permeant to ions and molecules of up to $1 \mathrm{kDa}$

\footnotetext{
Received Feb. 2, 1998; revised June 22, 1998; accepted July 22, 1998.

This work was supported by Wellcome Trust Grant 050133 to J.G.P. and D.L.B., and by a Medical Research Council program grant to W.H.E. We thank Dr. Patricia Martin for her contribution in the Northern blot analysis, and Dr. Anne Logan (University of Birmingham) for the sample of anti-bFGF antibody.

B.N. and H.M. contributed equally to this experimental work.

Correspondence should be addressed to John G. Parnavelas, Department of Anatomy and Developmental Biology, University College London, Gower Street, London WC1E 6BT, UK.

Dr. Nadarajah's present address: Department of Anatomy and Neurobiology, Washington University School of Medicine, St. Louis, MO 63110.

Dr. Makarenkova's present address: Skirball Institute of Biomolecular Medicine, New York, NY 10016.

Copyright (ㄷ) 1998 Society for Neuroscience $\quad 0270-6474 / 98 / 187881-10 \$ 05.00 / 0$
}

(Bennett et al., 1991). Mapping studies with site-specific antibodies have shown that connexins contain two extracellular loops, four transmembrane segments, and three cytoplasmic domains (a short amino terminus, an intracellular loop, and a $\mathrm{C}$ terminus of variable length) (Bennett et al., 1991). Fourteen rodent connexins have been identified, and in the developing and adult brain connexins (Cxs), Cxs 26, 32, and 43 are the major isoforms (Dermietzel and Spray, 1993; Kumar and Gilula, 1996; Nadarajah et al., 1996, 1997).

Recently it has been determined that intercellular coupling in the ventricular zone is a dynamic process involving proliferating cells but not migrating or postmitotic neurons (Bittman et al., 1997). The mechanism for such selective coupling is presently unclear. Because gap junctional communication is known to be regulated by growth factors (Lau et al., 1992; Doble and Kardami, 1995; Doble et al., 1996), we hypothesized that bFGF, present at high levels in the ventricular zone (Weise et al., 1993), may exert a regulatory effect on cell coupling at the early stages of corticogenesis. Using immunocytochemical, biochemical, molecular, and functional approaches, we have demonstrated that application of bFGF to cortical cells in culture resulted in higher levels of $\mathrm{Cx} 43$ mRNA and protein. Furthermore, intracellular injections of Lucifer yellow revealed that this growth factor increased coupling between cortical progenitor cells.

\section{MATERIALS AND METHODS}

Connexin antibodies. The anti-peptide antibodies used in the present study have been used recently to demonstrate the distribution of connexins in the adult and developing cerebral cortex (Nadarajah et al., 1996, 1997). The Cx 26 antibody was raised against the amino acid sequence 106-119 located in the intracellular loop of rodent Cx 26 and has been characterized by immunocytochemistry and Western blotting in various rodent and human tissues (Monaghan et al., 1994, 1996). The Cx 43 antibody, raised against residues 131-142 located in the intracellular loop of rodent $\mathrm{Cx} 43$, has also been characterized extensively (Becker et al., 1995; Carter et al., 1996; Monaghan et al., 1996). In addition, antibodies generated against residues $1-16$ of the amino terminus and 314-325 of the c-terminal end of rodent Cx 43 (Becker et al., 1995) were used to corroborate the immunoreactivity obtained with the antibody made against the intracellular loop. Further confirmation was obtained 
with a monoclonal Cx 43 antibody (Affinity) raised against a sequence at the $\mathrm{C}$ terminus.

Cortical cell cultures. The cerebral cortices of E16 rat brains were dissected, cleared of meninges, and enzymatically dissociated by incubation in DMEM (ICN Biochemicals, Montréal, Québec, Canada), containing $0.05 \%$ trypsin (ICN) and $0.001 \%$ DNase I (Boehringer Mannheim, Indianapolis, IN), for $45 \mathrm{~min}$ at $37^{\circ} \mathrm{C}$. After washing in $\mathrm{Ca}^{2+}$ $\mathrm{Mg}^{2+}$-free HBSS, treatment was continued with $0.025 \%$ trypsin, $0.001 \%$ DNase I, and 0.5 mm EDTA (Sigma, St. Louis, MO) in HBSS for $15 \mathrm{~min}$. Inactivation of trypsin was performed by the addition of $10 \%$ heatinactivated fetal calf serum (FCS) (Life Technologies, Gaithersburg, $\mathrm{MD})$, and the tissue pieces were dissociated by gentle trituration using a pipette. The resulting cell suspension was centrifuged and resuspended in DMEM/F12 (Sigma). Cells were plated on coverslips coated with poly-L-lysine $(10 \mathrm{mg} / \mathrm{ml}$; Sigma) and laminin $(5 \mathrm{mg} / \mathrm{ml}$; Sigma) at a density of $2.5 \times 10^{5}$ cells/coverslip and maintained for $24 \mathrm{hr}$ in DMEM/ F12 containing $10 \% \mathrm{FCS}, 2 \mathrm{mM}$ L-glutamine (ICN), and penicillin/ streptomycin (ICN).

Most cultures were maintained in media containing $10 \%$ FCS for 24 hr, but some were transferred to $0.5 \%$ FCS after the initial $12 \mathrm{hr}$ before bFGF treatment. To test the effects of bFGF, cells were treated with 10-30 ng/ml of the growth factor (recombinant human bFGF) (Promega, Madison, WI) for $4 \mathrm{hr}$ in serum-free medium; cultures maintained in DMEM/F12 for the same length of time were used as controls. Other cultures were pretreated with $10 \mathrm{~mm}$ 5-methyl thioadenosine (MTA) (Sigma) for $30 \mathrm{~min}$ followed by application of MTA and bFGF for $4 \mathrm{hr}$, or with bFGF for $4 \mathrm{hr}$ followed by addition of medium containing 40 $\mu \mathrm{g} / \mathrm{ml}$ of cycloheximide for $6 \mathrm{hr}$. The rate of cell proliferation in control and bFGF-treated cultures was determined as the proportion of cells that incorporated bromodeoxyuridine (BrdU) after a $3 \mathrm{hr}$ exposure to this S-phase marker; $10 \mu \mathrm{M}$ BrdU was added to the culture medium $3 \mathrm{hr}$ after exposure to $10 \mathrm{ng}$ of the growth factor.

Immunoprecipitation. Cultures treated with $20 \mathrm{ng}$ of bFGF and control cultures were washed in PBS and lysed on ice using RIPA buffer (1\% NP-40, $0.5 \%$ deoxycholate, $0.1 \%$ SDS, $50 \mathrm{~mm}$ Tris HCl, $150 \mathrm{~mm} \mathrm{NaCl}$, pH 8.0) containing anti-proteolytic components (Complite; Boehringer Mannheim), $2 \mathrm{~mm}$ sodium orthovanadate and $2 \mathrm{~mm}$ PMSF. The lysates were centrifuged at $40,000 \times g$ for $1 \mathrm{hr}$, and the supernatants were incubated with $50 \mu$ l of washed Protein A Sepharose CL-4B beads (Pharmacia Biotech, Piscataway, NJ) for $45 \mathrm{~min}$. After the initial incubation, the beads were pelleted by low-speed centrifugation, and the supernatants were treated with a mixture of $\mathrm{Cx} 43$ polyclonal antibodies overnight. The treated samples were then incubated with Sepharose beads for an additional $45 \mathrm{~min}$, centrifuged briefly, and resuspended by vortexing in RIPA buffer. After washing for three to four times in buffer (50 mm Tris-HCl, pH 7.5, 0.5\% Tween, $150 \mathrm{~mm} \mathrm{NaCl,} 0.1 \mathrm{~mm}$ EDTA, $\mathrm{pH} 7.5)$ and in PBS, the pellets were resuspended in $40 \mu \mathrm{l}$ of sample buffer, boiled for $5 \mathrm{~min}$, and centrifuged. The supernatant fraction was analyzed by $10 \%$ SDS-PAGE (Laemmli, 1970) and detected with antibFGF monoclonal antibody (dilution 1:1000) (gift of Dr. A. Logan, University of Birmingham).

Western blotting. Control and treated cultures were lysed using a triple detergent lysis buffer containing $0.1 \%$ SDS, $1 \%$ NP-40, $0.5 \%$ deoxycholate, $50 \mathrm{~mm}$ Tris $\mathrm{HCl}$, and $50 \mathrm{~mm} \mathrm{NaCl}$, pH 8.0. All steps were performed at $4^{\circ} \mathrm{C}$, and a mixture of protease inhibitors $(10 \mu \mathrm{g} / \mathrm{ml}$ each of leupeptin, aprotenin, and pepstatin A), 2 mM sodium orthovanadate, and freshly prepared PMSF (1 mM) were added at intervals throughout the extraction procedure. The cell lysates were collected and centrifuged at $12,000 \times g$ for $30 \mathrm{~min}$ at $4^{\circ} \mathrm{C}$, and pellets were resuspended in sample buffer. Protein $(50 \mu \mathrm{g})$ was analyzed by $10 \%$ SDS-PAGE and transferred onto a nitrocellulose membrane. Molecular markers (New England Biolabs, Beverly, MA) $\left(M_{\mathrm{r}} 14.3-200 \mathrm{~K}\right)$ were used. Membranes, blocked with $5 \%$ dry skimmed milk in Tris $\mathrm{HCl}, \mathrm{pH} 8.0$, containing $0.1 \%$ Tween 20 (TPBST) for $30 \mathrm{~min}$ were incubated with $\mathrm{Cx}$ antibodies $(1: 1000)$ overnight at $4^{\circ} \mathrm{C}$. After incubation with goat anti-rabbit or rabbit anti-mouse conjugated to HRP (Bio-Rad, Hercules, CA) (1:200), antibody binding was visualized using the enhanced chemiluminescence (ECL, Amersham, Arlington Heights, IL) system. In some cases, gels containing duplicate samples were stained with Coomasie blue to visualize all bands. Control blots were performed with heart and liver tissue using the same lysis buffer.

Northern blotting. Total RNA was extracted from control and bFGFtreated cultures $\left(\sim 6 \times 10^{6}\right.$ cells for each treatment $)$ by a single-step method using Ultraspec (Biotecx, Houston, TX). Five micrograms of total RNA were resolved by $1 \%$ agarose-formaldehyde gel containing ethidium bromide. Gels were capillary-blotted onto a nylon membrane (Hybond-N ${ }^{+}$) (Amersham) overnight, and fixed by UV light. Digoxigenin (DIG)-labeled Cx 43 antisense RNA probes were produced from the vector pcDNA 1 Neo (Invitrogen, San Diego, CA) containing rat Cx 43 cDNA (Beyer et al., 1987). Hybridization and washing were performed under stringent conditions, and the detection of bands was performed by the DIG colorimetric system (Boehringer Mannheim).

Immunocytochemistry. Cell cultures were fixed for connexin immunocytochemistry with $2 \%$ paraformaldehyde in $0.1 \mathrm{M}$ PBS, pH 7.4. Cells were first placed in medium containing $5 \%$ normal goat serum, $0.1 \%$ Triton X-100, and 0.1 PBS to block nonspecific labeling, before incubation with $\mathrm{Cx}$ antibodies $(1: 100)$ at $4^{\circ} \mathrm{C}$ overnight, followed by goat anti-rabbit conjugated to FITC (Vector Laboratories, Burlingame, CA; $1: 100)$ as a second layer. Cells were counterstained with propidium iodide and visualized with a Leica TCS 4D laser-scanning confocal microscope. Cryostat-cut sections of rapidly frozen liver and heart tissues were used as positive controls. Peptide competition assays (data not shown) and omission of primary antibodies showed a marked reduction and absence of immunolabeling, respectively.

In experiments performed to assess the rate of cell proliferation, cultures exposed to BrdU were immunostained first with the polyclonal Cx 43 antibody and then with a monoclonal antibody against BrdU (1:500; Sigma) (Cavanagh et al., 1997). In addition, some cultures were stained with a monoclonal antibody for proliferating cell nuclear antigen (PCNA) (1:1000; Sigma) to label the proliferating cell population.

Intracellular injections. Single cells from confluent cultures were selected for injection, using a fixed-stage epifluorescence microscope ( $\mathrm{Mi}$ croinstruments, Oxford, UK) and interference contrast optics with a $40 \times$ ELWD objective (Nikon). A small amount of 4\% Lucifer yellow (Sigma) was introduced into the tip of a glass microelectrode (Glass Company of America) (resistance 30-50 M $\Omega$ ). Lucifer yellow was injected into single cells by brief application of negative current and left to diff use for $2 \mathrm{~min}$. The membrane potentials of injected cells were monitored using a standard electrophysiological apparatus. Spread of Lucifer yellow was monitored by its fluorescence under a Zeiss filter set (06). The results are based on a minimum of 40 cell injections each from control and treated cultures.

\section{RESULTS}

\section{Effect of bFGF on connexin 43 expression in cortical progenitor cells}

In vivo and in vitro studies have demonstrated that Cxs 26 and 43 are the major gap junction proteins expressed by cortical cells during prenatal development (Nadarajah et al., 1997). In the present work, Cx 43 immunocytochemistry showed intense intracellular staining in cells maintained in $10 \%$ FCS for $24 \mathrm{hr}$ before exposure to bFGF in serum-free medium for $4 \mathrm{hr}$. In contrast, control cultures that were maintained in serum for $24 \mathrm{hr}$ followed by $4 \mathrm{hr}$ in serum-free medium showed punctate labeling on the cell surface characteristic of gap junctional contact plaques (Nadarajah et al., 1997) (Fig. 1 $a-c$ ). Western blot analysis, using site-specific antibodies to $\mathrm{Cx} 43$, identified two proteins of $M_{\mathrm{r}} 45$ and $76 \mathrm{~K}$ in bFGF-treated cultures, with the higher $M_{\mathrm{r}}$ component being more prominent (Fig. $2 a, b$ ). An increased intensity of both bands was observed as the concentration of bFGF was increased from 10 to $20 \mathrm{ng} / \mathrm{ml}$ (Fig. $2 b$ ). To verify the above findings, a range of anti-peptide antibodies generated to various amino acid sequences present at the amino and $\mathrm{C}$ termini were used as well as a monoclonal antibody to an epitope on the C-terminal tail of $\mathrm{Cx}$ 43. Immunocytochemical and Western blot analyses performed with these antibodies again confirmed that the expression of Cx 43 increased in response to bFGF treatment (Figs. 1d,e,g,h, $2 c, d)$. The localization of the higher $M_{\mathrm{r}}$ component in membrane extracts of cardiac tissue (Fig. 2e) (Harfst et al., 1990) showed that this protein is also expressed in this tissue and is not induced by in vitro conditions. Immunocytochemical analysis with an antibody specific to $\mathrm{Cx} 26$, the other major isoform expressed, did not show differential staining between control and bFGF-treated cul- 

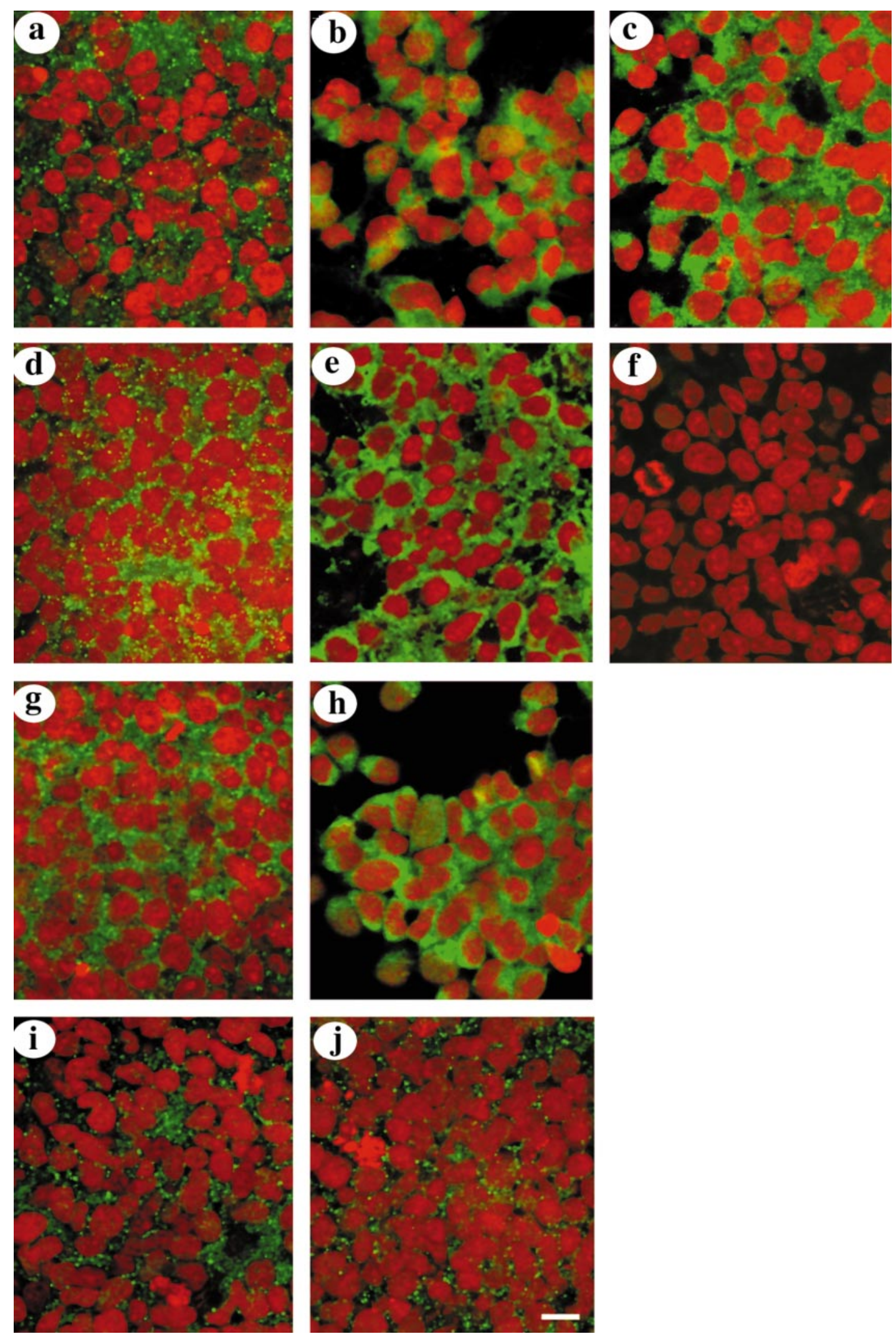

Figure 1. Immunocytochemical analysis of cells maintained in $10 \%$ FCS for $24 \mathrm{hr}$ before exposure to bFGF in serum-free medium for 4 hr. Connexin staining is shown in green, and propidium iodide labeling of nuclei is shown in red. $a-c$, Images taken from control $(a)$ and from cultures treated with 10 and $20 \mathrm{ng}$ of bFGF $(b, c)$, all stained for $\mathrm{Cx} 43$ with a polyclonal antibody raised against the intracellular loop of the protein. $d, e, g, h$, Images collected from control $(d, g)$ and from cultures treated with $20 \mathrm{ng}$ of bFGF $(e, h)$ stained for $\mathrm{Cx} 43$ with polyclonal antibodies raised against the amino and $\mathrm{C}$ termini, respectively. Note the intracellular labeling of $\mathrm{Cx} 43$ in all treated cultures. $f$, Absence of labeling in cells when the primary antibody was omitted. (i, j) Examples of images taken from control and from cultures treated with $20 \mathrm{ng}$ of bFGF and labeled for Cx 26. Scale bar, $100 \mu \mathrm{m}$. 


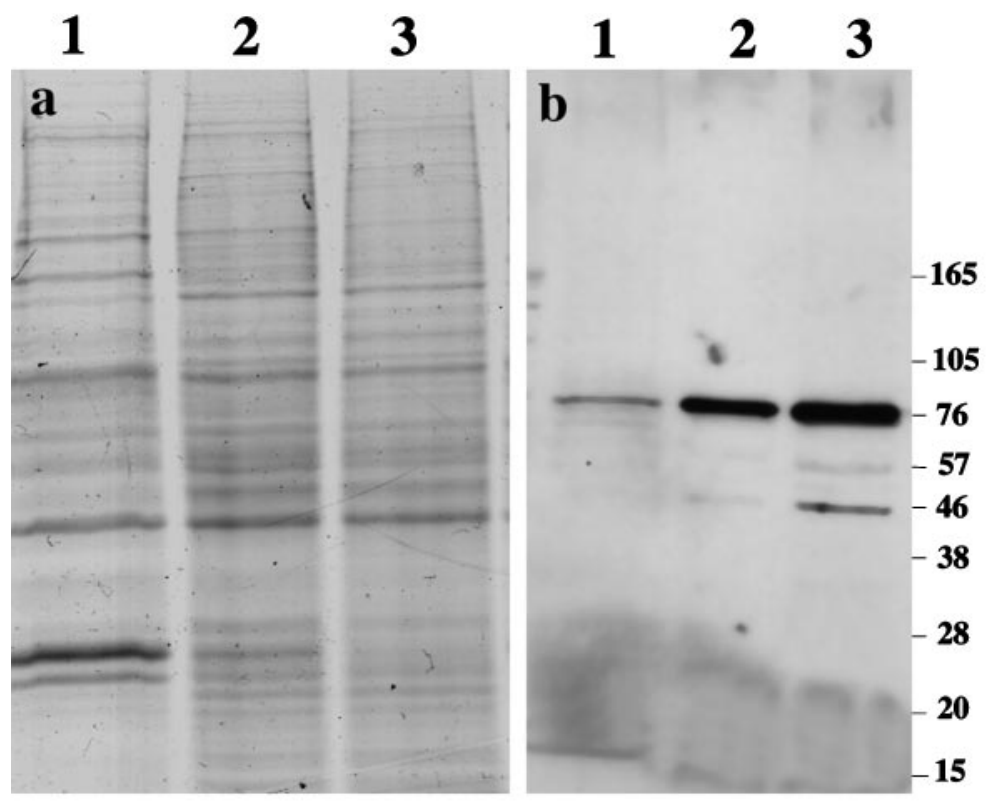

Figure 2. Localization of $\mathrm{Cx} 43$ in Western blots of cultures maintained in $10 \%$ FCS before bFGF treatment. $a$, Coomassie blue-stained gel containing the same samples as in $b . b$, Localization of 45 and $76 \mathrm{kDa}$ bands using an anti-Cx 43 polyclonal antibody raised against the intracellular loop of the protein. $c, d$, Immunolocalization of 45 and $76 \mathrm{kDa}$ bands with polyclonal $(c)$ and monoclonal $(d)$ antibodies raised against the $\mathrm{C}$ terminus of the protein. $a-d$, Lanes 1-3 correspond to samples from control and from cultures treated with 10 and $20 \mathrm{ng}$ of bFGF, respectively. $e$, Detection of 45 and $76 \mathrm{kDa}$ bands in different fractions of heart extracts. Lane 1 corresponds to whole heart extract, and lanes 2 and 3 correspond to supernatant and pellet of the membrane fractions, respectively.
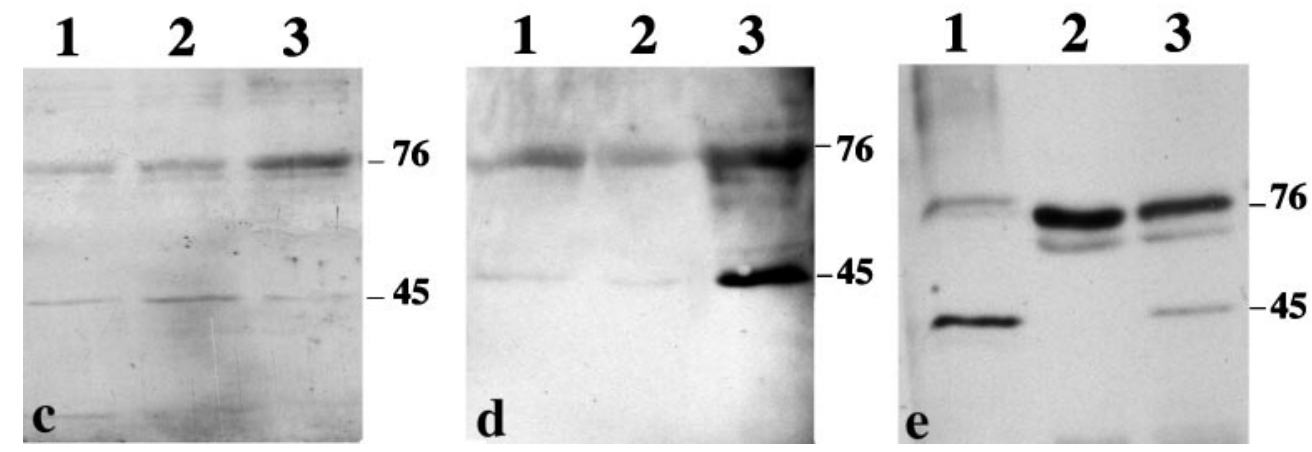

tures (Fig. 1i,j). Also, the expression of this connexin protein did not appear to change in Western blots (data not shown).

Because the presence of serum increases the expression of $\mathrm{Cx}$ 43 (Acevedo and Bertram, 1995), experiments were performed in which cell cultures were initially maintained in $10 \%$ FCS and later changed to a medium containing $0.5 \%$ serum before bFGF treatment was commenced. It was observed that exposure of cells to a medium with low serum content reduced the expression of Cx 43, but bFGF-treated cultures now showed intracellular Cx 43 staining in contrast to the cell surface staining observed in control cultures (Fig. $3 a-c$ ).

The above results indicate that short-term exposure of cortical cells to bFGF results in the induction of $\mathrm{Cx} 43$ expression. However, although cross-reaction between the $\mathrm{Cx} 43$ antibodies and a different protein was unlikely as suggested by the use of a range of $\mathrm{Cx}$ antibodies, we investigated the possibility that a modified higher molecular weight protein was induced after bFGF treatment. Cells that were initially conditioned in serum and later treated with bFGF were transferred for up to $6 \mathrm{hr}$ into a medium containing $40 \mu \mathrm{g} / \mathrm{ml}$ of cycloheximide, an inhibitor of protein synthesis, for it was hypothesized that $\mathrm{Cx} 43$ production would be arrested at this concentration of the inhibitor. Immunocytochemical analysis showed these cells to contain markedly reduced Cx 43 staining (Fig. $3 d-f$ ). Moreover, the characteristic punctate labeling located on the surface of these cells was depen-

dent on the concentration of the growth factor; punctate labeling with antibodies to $\mathrm{Cx} 43$ was observed in cells exposed to $20 \mathrm{ng}$ of bFGF (Fig. 3f) but was much reduced in those treated with $10 \mathrm{ng}$ (Fig. 3e). Western blot analysis of parallel cultures showed the 45 $\mathrm{kDa}$ band in cultures treated with 20 and $30 \mathrm{ng}$ of bFGF, respectively (Fig. $4 a$ ). These results suggest that after cycloheximide treatment, intracellular stores of connexins produced in abundance during bFGF treatment have been transported to the plasma membrane and assembled into gap junctions.

Binding of bFGF to its high-affinity receptors leads to activation of tyrosine kinases (Lee et al., 1989; Dionne et al., 1990). To investigate whether activation of the $\mathrm{Cx} 43$ gene is mediated through the same kinase system, we used MTA, a specific inhibitor of bFGF-stimulated receptor tyrosine kinase (Maher, 1993). In the study of Maher (1993), it was shown that treatment of BALB/c 3T3 cells with bFGF led to rapid tyrosine phosphorylation of proteins that was inhibited by MTA in a dose-dependent manner, with complete inhibition achieved at concentrations between 3 and $10 \mathrm{~mm}$. Using $10 \mathrm{~mm}$ MTA, we demonstrated that cells treated with bFGF in the presence of MTA did not show intracellular staining for $\mathrm{Cx} 43$; however, punctate cell surface labeling was observed (Fig. $3 g-i$ ). Furthermore, in Western blots, the $45 \mathrm{kDa}$ band in the control and treated samples were of equal intensity (Fig. $4 b$ ), suggesting that in the presence of MTA the effect of bFGF is inhibited. These findings demonstrate that the 

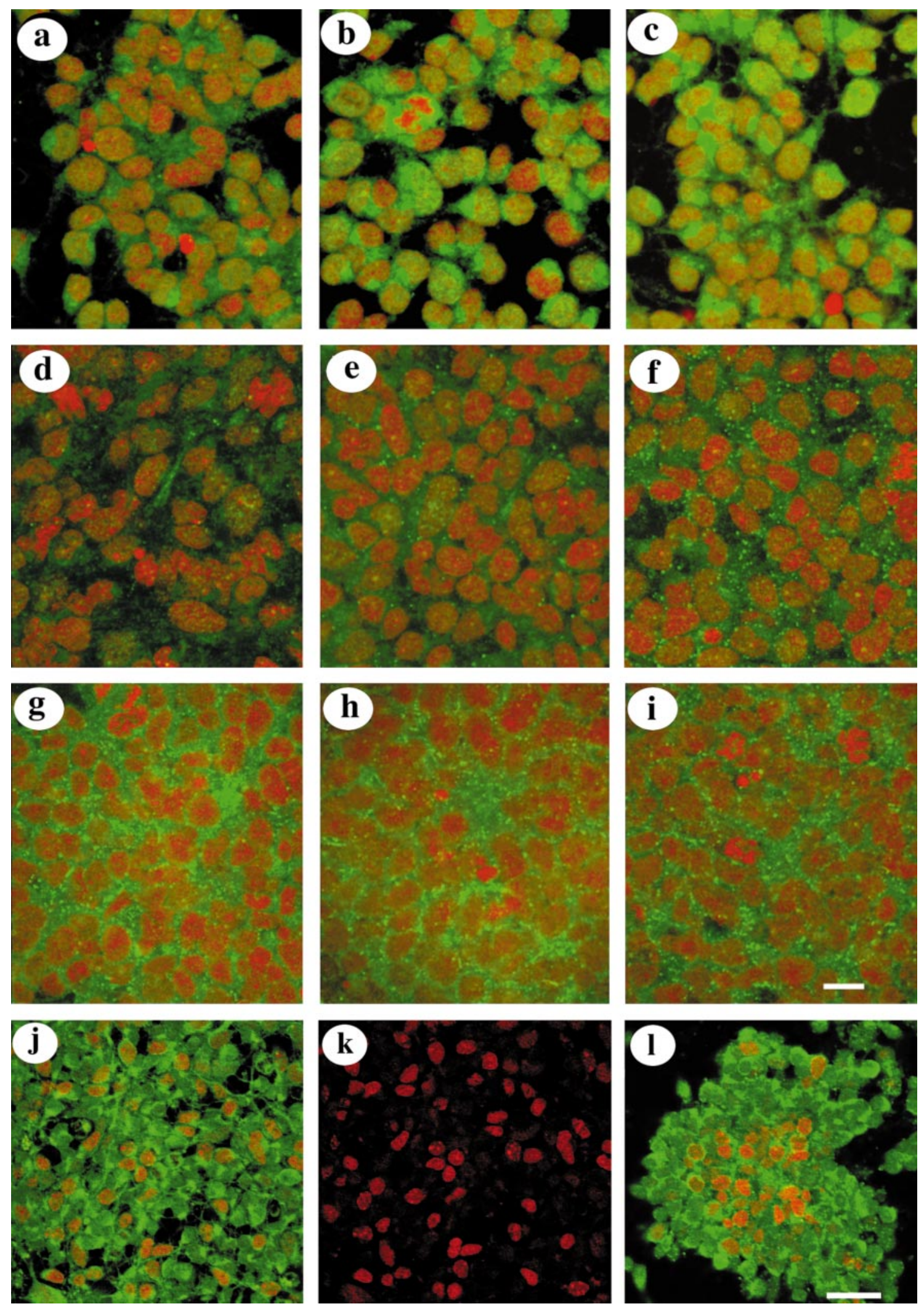

Figure 3. Immunocytochemical analyses of cultures after different treatments. Connexin staining is shown in green, and propidium iodide labeling of nuclei is shown in red. $a-c$, Images taken from cultures maintained initially in $10 \%$ FCS and later changed to medium containing $0.5 \%$ serum before exposure to bFGF in serum-free medium for $4 \mathrm{hr} . d-f$, Images of cultures that were transferred to medium containing cycloheximide for a period up to $6 \mathrm{hr}$ after bFGF treatment. $g-i$, Images of cultures treated with MTA and bFGF. $a, d$, and $g$ are images of control cultures, whereas $b, e$, and $h$ and $c$, $f$, and $i$ are from cultures treated with 10 and $20 \mathrm{ng}$ of bFGF, respectively. Scale bar: $a-i, 100 \mu \mathrm{m} . j, k$, Images of bFGF-treated cultures stained for BrdU $(k)$ or double-labeled for BrdU and Cx $43(j)$. $(l)$ Image of a culture double-labeled for PCNA and Cx 43. Connexin staining is shown in green, and BrdU/PCNA-labeled nuclei are shown in red. Scale bar: $j-l, 80 \mu \mathrm{m}$. 

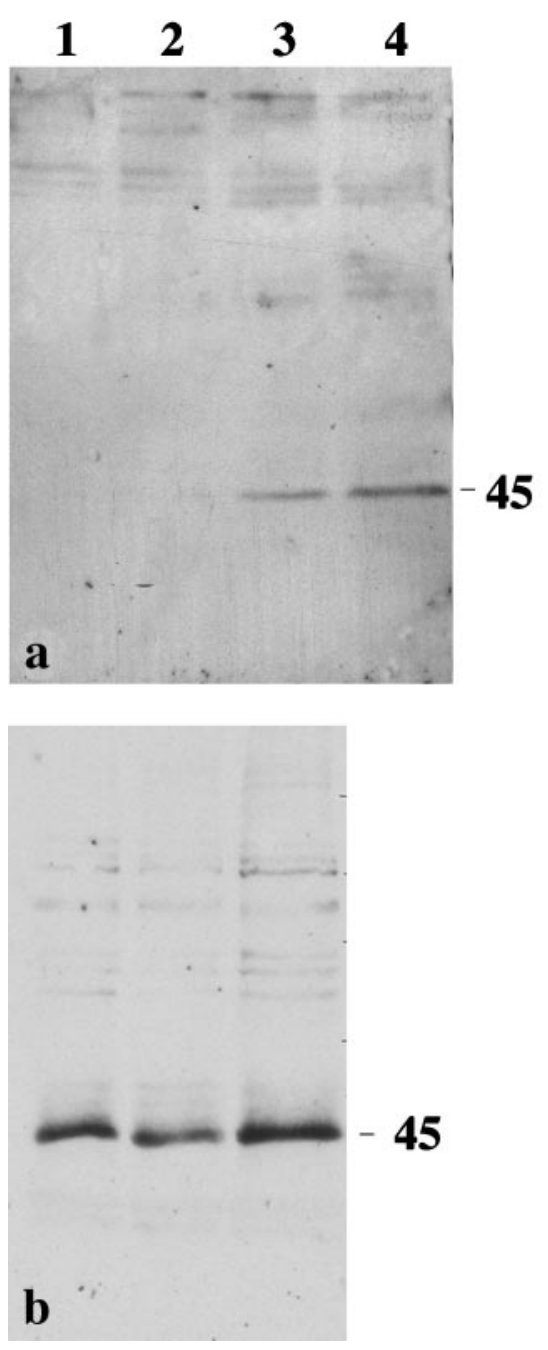

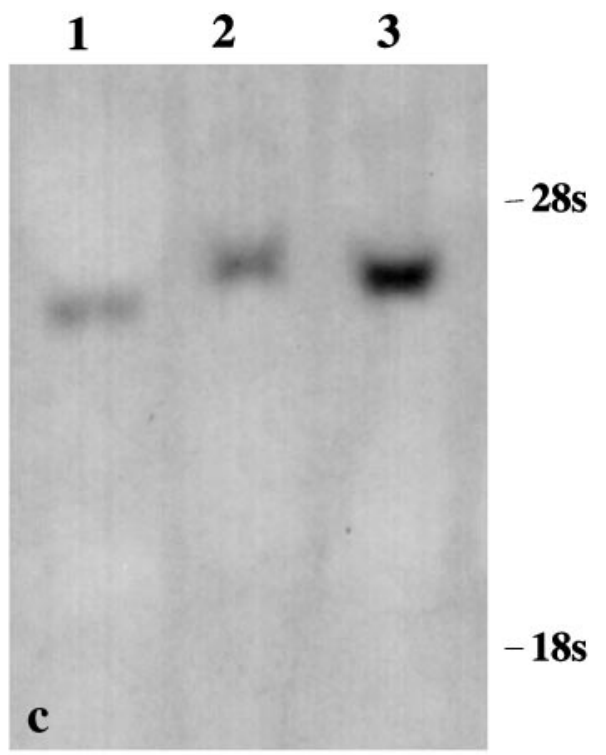

Figure 4. Western blot analyses of cultures after different treatments. $a$, Detection of a $45 \mathrm{kDa}$ band in cultures that were transferred to a medium containing cycloheximide for a period up to $6 \mathrm{hr}$ after treatment with bFGF. $b$, Detection of $45 \mathrm{kDa}$ bands in cultures treated with MTA and bFGF. Lanes 1-4 correspond to samples from control, and from cultures treated with 10, 20, and $30 \mathrm{ng}$ of bFGF. The position of the molecular markers is given on the right. $c$, Northern blot of $\mathrm{Cx} 43$ from cultures exposed to bFGF. Lanes 1-3 correspond to control and to cultures treated with 10 and $20 \mathrm{ng}$ of bFGF; note the increased abundance of $\mathrm{Cx} 43$ transcripts in the sample from a culture treated with $20 \mathrm{ng}$ of bFGF.

effect of bFGF on Cx 43 expression is triggered by the activation of receptor tyrosine kinase.

Assessment of the rate of cell proliferation, after a $3 \mathrm{hr}$ exposure to BrdU, showed no difference between the control and bFGF-treated cultures $(35 \pm 5.3 \%)$. Further analysis indicated that in the cultures treated with the growth factor, only $47 \pm 5.3 \%$ of the BrdU-labeled cells contained intense Cx 43 staining (Fig. $3 j, k)$. In addition, both PCNA-positive and -negative cells in these cultures contained cytoplasmic $\mathrm{Cx} 43$ staining (Fig. 3l), thereby suggesting that the expression of this protein was upregulated in proliferating and nonproliferating (most likely postmitotic) cell populations.

Earlier studies (Kardami et al., 1991) have demonstrated a physical association between endogenous bFGF and gap junctions composed of $\mathrm{Cx} 43$. To investigate whether the $\mathrm{Cx} 43$ produced during the growth factor treatment interacts with the applied recombinant bFGF, control and treated cell cultures were immunoprecipitated using Cx 43 antibodies and detected by Western blotting with anti-bFGF serum. The results showed the localization of a higher molecular weight protein corresponding to 76 $\mathrm{kDa}$ in the treated cultures, suggesting an intermolecular association between Cx 43 and the bFGF (Fig. 5).

Northern blot analyses showed that Cx 43 mRNA was also increased in response to bFGF treatment (Fig. 4c). Although this suggested that Cx 43 protein levels may have been elevated mainly because of an increase in the rate of transcription of this connexin, an increase in the stability of mRNA may also have been contributary.

\section{Effect of bFGF on gap junctional coupling}

When single cells in confluent monolayers of control and bFGFtreated cultures were injected with Lucifer yellow, dye transfer to neighboring cells was observed in most cases (Fig. 6); a few of the injected cells did not couple to any other cells in the culture. Coupled cells appeared in clusters of 2-13 cells. Overall, there were fewer noncoupled cells and larger clusters of coupled cells in the bFGF-treated cultures compared with controls (two-tailed Mann-Whitney $U$ test; $p<0.05$ ) (Fig. 7).

\section{DISCUSSION}

We have used immunocytochemical, biochemical, molecular, and functional approaches to investigate the effects of bFGF on the expression of connexins and the extent of gap junctional communication between progenitor cells in the developing cerebral cortex. We have demonstrated that after exposure of these cells to exogenous bFGF, the $\mathrm{Cx} 43$ gene was induced through a receptor tyrosine kinase pathway to increase connexin expression; this was associated with an increase in intercellular coupling mediated by gap junctions. 


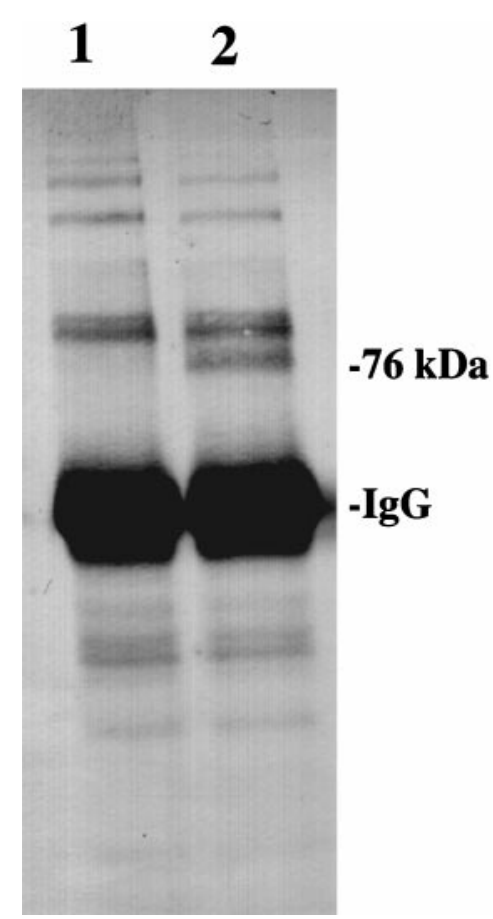

Figure 5. Localization of a higher molecular weight protein corresponding to a $76 \mathrm{kDa}$ band in cultures immunoprecipitated using $\mathrm{Cx}_{\mathbf{X}} 43$ antibodies and detected with an anti-bFGF serum. Lanes 1 and 2 correspond to control and cultures treated with $20 \mathrm{ng}$ of bFGF; note the absence of this band in the control cultures.

\section{Effect of bFGF on connexin expression in cortical progenitor cells}

We have recently shown that cells in the ventricular zone of the developing rat cerebral cortex express Cxs 26 and 43 as early as embryonic day (E)12, increasing the expression of these proteins until E16 (Nadarajah et al., 1997). The demonstration of connexin expression and the reported functional coupling between progenitor cells (LoTurco and Kriegstein, 1991; Bittman et al., 1997) is of interest, for gap junctions are permeant to mitogens and morphogens (Caveney, 1985; Guthrie and Gilula, 1989). In vitro studies involving various cell systems have shown that growth factors have a modulatory effect on gap junctional communication. For example, it has been shown that epidermal growth factor (Madhukar et al., 1989; Lau et al., 1992) and transforming growth factor $\beta$ (Maldonado et al., 1988) diminish gap junctional coupling, whereas fibroblast growth factor 4 upregulates the expression of Cxs 32 and 43 and increases cell-cell coupling (Makarenkova et al., 1997). Also, exposure of microvascular endothelial cells and cardiac fibroblasts to bFGF has been found to enhance expression of Cx 43 and increase coupling (Pepper and Meda, 1992; Doble and Kardami, 1995). In contrast, independent studies using cardiac myocytes have reported a decrease in metabolic coupling when exposed to bFGF (Doble et al., 1996).

In the present study, a short-term exposure of cortical progenitor cells to bFGF resulted in a concentration-dependent increase in the expression of $\mathrm{Cx} 43$. When protein synthesis was arrested with cycloheximide after exposure of cells to bFGF, both the punctate labeling of membranes and the corresponding $45 \mathrm{kDa}$ band were visible only in those samples exposed to higher concentrations of bFGF. Because the half life of gap junctions in vitro is between 1.5 and $3 \mathrm{hr}$ (Musil et al., 1990), the presence of punctate labeling after a $4 \mathrm{hr}$ post-treatment with cycloheximide suggests that $\mathrm{Cx} 43$ gap junction plaques must have been replenished from the intracellular pool of this protein produced in abundance during bFGF treatment. In this context, it has been reported that $\mathrm{Cx} 43$ stores residing in the endoplasmic reticulum/ Golgi complex are not subject to rapid degradation and are available for the assembly of new gap junction channels (Laird et al., 1995).

Another outcome of this study is the immunolocalization of a $76 \mathrm{kDa}$ protein that responded in a concentration-dependent manner to bFGF treatment. The localization of this protein demonstrated by a panel of $\mathrm{Cx} 43$ antibodies raised against amino acids located in the intracellular loop, amino, and $\mathrm{C}$ termini confirmed the authenticity of this connexin-related band. Furthermore, comparison of the amino acid sequence of the three epitopes that were used to generate the various cytoplasmic sites of Cx 43 polyclonal antibodies identified only rodent, chick, bovine, and human $\mathrm{Cx} 43$ with overlapping sequence homology. Because it is known that $\mathrm{Cx} 43$ is encoded by a transcript of 3.1 $\mathrm{kb}$ (Beyer et al., 1987), the presence of a single transcript band of this size implies that the $76 \mathrm{kDa}$ protein may be the result of a protein-protein interaction. In this context, it is pertinent to note that biochemical and ultrastructural evidence has shown a physical association between endogenous bFGF and gap junctions composed of $\mathrm{Cx} 43$ between the intercalated disks of cardiomyocytes (Kardami et al., 1991) and between astrocytes of rat brain (Yamamoto et al., 1991). Kardami and colleagues (1991), using antisera against bFGF, have demonstrated the presence of 18,28 , 45 , and $72 \mathrm{kDa}$ bands in heart ventricular preparations enriched with gap junctions and concluded that these immunoreactive bands are likely to be oligomers of bFGF. Because bFGF immunoreactivity was confined to gap junctions and not to nonjunctional membranes, these authors suggested that the epitopes of the antisera are either an integral part of, or exist in close association with, gap junctions composed of $\mathrm{Cx} 43$. It is possible, therefore, that in cortical cultures the $\mathrm{Cx} 43$ produced in abundance during growth factor treatment may have interacted temporally with intramolecular and intermolecular complexes of $\mathrm{bFGF}$ and given rise to the observed $76 \mathrm{kDa}$ band.

\section{Effect of bFGF on functional coupling}

Intercellular coupling is regulated by the assembly and breakdown of connexons and gap junctions and by channel gating mechanisms. In the present study, injection of Lucifer yellow into cortical cells showed that most cells were coupled into clusters and that these clusters tended to contain more cells in the bFGFtreated cultures than in the controls. It may be that larger clusters of communicating cells result from the insertion of newly synthesized $\mathrm{Cx} 43$ into the membrane, although a possible modulation of channel conductance cannot be excluded. Cell cluster sizes varied considerably both in the control and treated culture, probably because of the heterogeneous nature of cortical cells expressing multiple connexins.

\section{Mechanism of induction of increased Cx $\mathbf{4 3}$ expression}

What mechanisms control the induction of $\mathrm{Cx} 43$ expression on exposure to bFGF? A family of receptors that bind bFGF has now been identified that possesses intrinsic tyrosine kinase activity (Lee et al., 1989; Dionne et al., 1990). Because treatment with MTA and bFGF did not result in an increase in the levels of $\mathrm{Cx}$ 43 , it is likely that the induction is a result of activation of the receptor tyrosine kinase pathway. Recent reports have suggested that growth factors bind to and stimulate their tyrosine kinase 

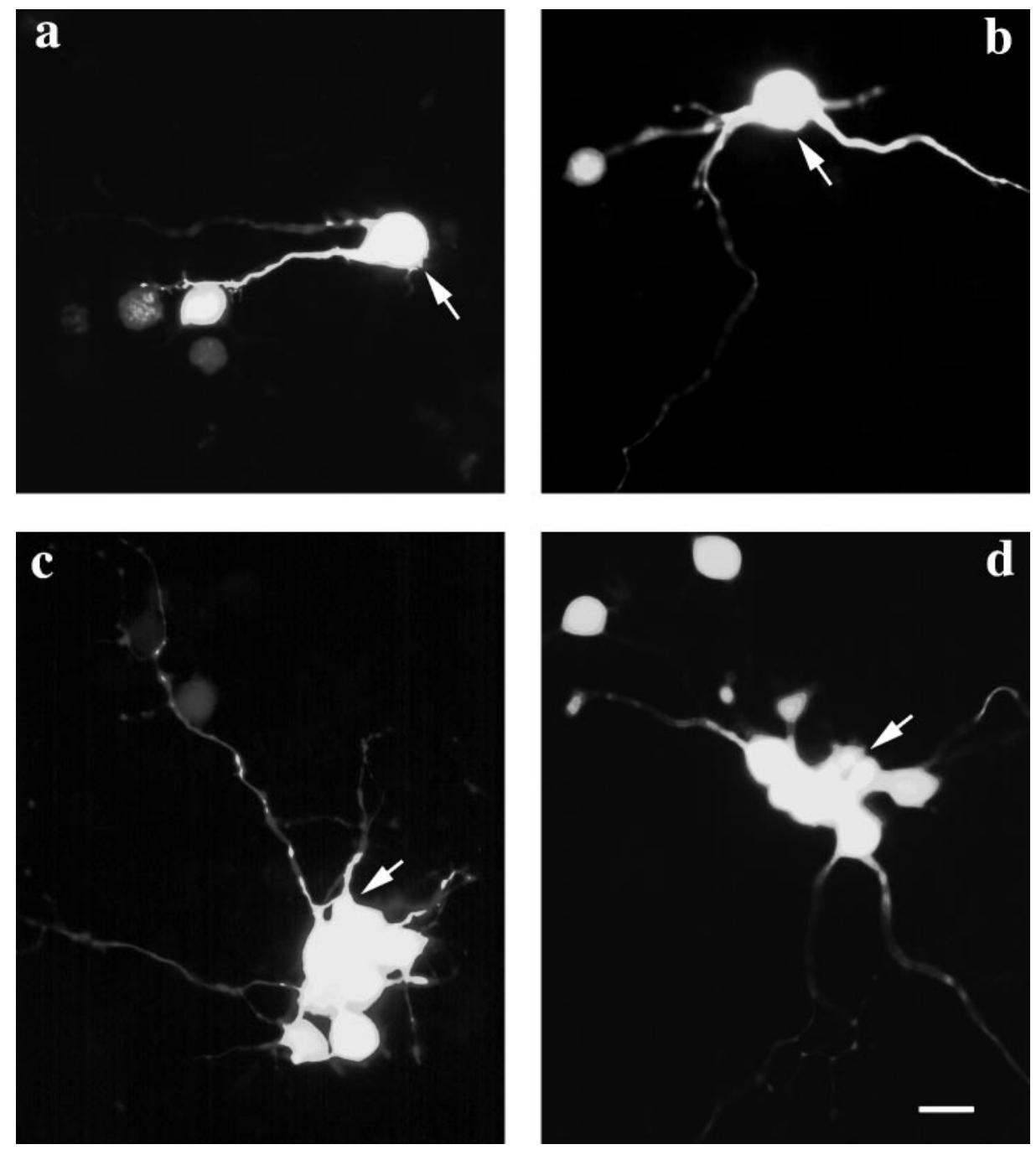

Figure 6. Lucifer yellow injections in cells in control $(a, b)$ and bFGF-treated $(c, d)$ cultures showed transfer of dye to neighboring cells. Note that the larger clusters of dye-coupled cells in treated cultures are brightly labeled, in contrast to the cells from control cultures. $\mathrm{Ar}$ rows point to the injected cells.

receptors that may trigger the downstream activation of many kinases through various second messenger systems (Ullrich and Schlessinger, 1990). Prominent among these is MAP kinase, which is phosphorylated in response to various extracellular signals (Boulton et al., 1991). Ghosh and Greenberg (1995) have shown that application of bFGF to embryonic cortical cells led to rapid induction of tyrosine phosphorylation of MAP kinase and increased c-fos expression. In this regard, it has been shown that the 5'-proximal promoter region of murine and human $\mathrm{Cx} 43$ gene contains activator protein 1 sites (AP-1 and AP-2) (Lefebvre et al., 1995; Geimonen et al., 1996) that may bind the transcription factor fos. Thus, it is possible that activation of MAP kinase and increased levels of c-fos would induce the AP-1-mediated transcription of $\mathrm{Cx} 43$ genes as shown by Geimonen et al. (1996).

The present results have important implications for the role of growth factors and gap junctions in growth and development. Although bFGF has been detected in the embryonic murine cerebral cortex as early as E9.5 (Nurcombe et al., 1993), mRNA and protein levels of the $18 \mathrm{kDa}$ isoform increase dramatically from E14 to E18 (Powell et al., 1991; Giordano et al., 1992; Weise et al., 1993). This increase occurs at the same time that the Cx 43 levels rise in the ventricular zone (Nadarajah et al., 1997). We have shown here that bFGF exerts its effects on both proliferating and nonproliferating (most likely postmitotic) cortical cell types,

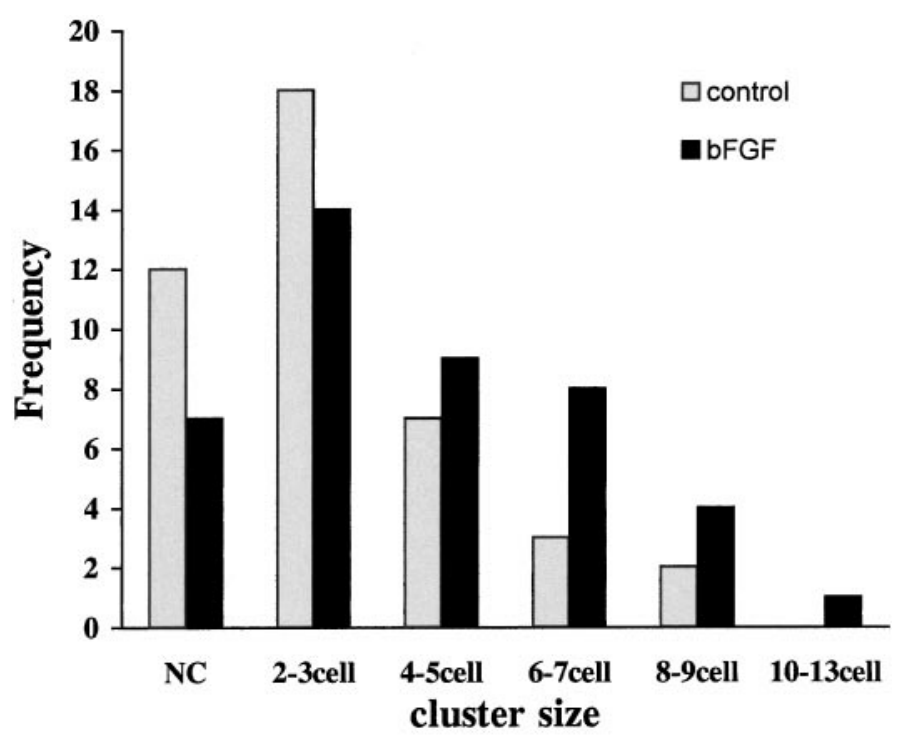

Figure 7. Frequency of cell coupling in control and bFGF-treated cultures. Treatment with $20 \mathrm{ng}$ of the growth factor resulted in the frequent presence of large clusters of coupled cells. $N C$, Noncoupled. 
and it is pertinent to note that in the treated cultures some of the coupled cells marked with Lucifer yellow showed extended neurites and displayed features characteristic of postmitotic neurons. Although we have found that not all BrdU-labeled cells expressed $\mathrm{Cx} 43$, it has been demonstrated that the mitogenic effects of bFGF are evident only when cortical cells are grown in clusters (Ghosh and Greenberg, 1995; Cavanagh et al., 1997). Thus, it is possible that the functional coupling induced by this growth factor is essential to keep progenitor cells, which otherwise would have differentiated, in the proliferative mode. In this regard, direct cell-cell interactions have been implicated in the process of proliferation of cortical progenitors in addition to the mitogenic action of bFGF (Temple and Davis, 1994; Ghosh and Greenberg, 1995). Taking these observations together with data showing an association between coupling and the cell cycle of neuroepithelial cells (Bittman et al., 1997), it is possible that gap junction channels provide a direct conduit for mitogens released on bFGF induction to effectively regulate proliferation. The results presented here provide evidence that gap junctional coupling may directly or indirectly regulate the proliferation of cortical progenitors cells and lend support for a role of gap junctions in growth control as hypothesized by Loewenstein (1979).

\section{REFERENCES}

Acevedo P, Bertram JS (1995) Liarozole potentiates the cancer chemopreventive activity of and the up-regulation of gap junctional communication and connexin43 expression by retinoic acid and beta-carotene in 10T1/2 cells. Carcinogenesis 16:2215-2222.

Becker DL, Evans WH, Green CR, Warner A (1995) Functional analysis of amino acid sequences in connexin43 involved in intercellular communication through gap junctions. J Cell Sci 108:1455-1467.

Bennett MVL, Barrio LC, Bargiello TA, Spray DC, Hertzberg E, Saez JC (1991) Gap junctions: new tools, new answers, new questions. Neuron 6:305-320.

Beyer EC, Paul DL, Goodenough DA (1987) Connexin 43: a protein from rat heart homologous to gap junction protein from liver. J Cell Biol 105:2621-2629.

Bittman K, Owens DF, Kriegstein AR, LoTurco JJ (1997) Cell coupling and uncoupling in the ventricular zone of developing neocortex. J Neurosci 17:7037-7044.

Boulton TG, Nye SH, Robbins DJ, Ip NY, Radziejewska E, Morgenbesser SD, DePinho RA, Panayotatos N, Cobb MH, Yancopoulos GD (1991) ERKs: a family of protein-serine/threonine kinases that are activated and tyrosine phosphorylated in response to insulin and NGF. Cell 17:663-675.

Carter TD, Chen XY, Carlile G, Kalapothakis E, Ogden D, Evans WH (1996) Porcine aortic endothelial gap junctions: identification and permeation by caged InsP3. J Cell Sci 109:1765-1773.

Cavanagh JFR, Mione MC, Pappas IS, Parnavelas JG (1997) Basic fibroblast growth factor prolongs the proliferation of rat cortical progenitor cells in vitro without altering their cell cycle parameters. Cereb Cortex 7:293-302.

Caveney S (1985) The role of gap junctions in development. Annu Rev Physiol 47:319-335.

Davis AA, Temple S (1994) A self-renewing multipotential stem cell in embryonic rat cerebral cortex. Nature 372:263-266.

Dermietzel R, Spray DC (1993) Gap junctions in the brain: where, what type, how many and why? Trends Neurosci 16:186-192.

Dionne CA, Crumley G, Bellot F, Kaplow JM, Searfoss G, Ruta M, Burgess WH, Jaye M, Schlessinger J (1990) Cloning and expression of two distinct high-affinity receptors cross-reacting with acidic and basic fibroblast growth factors. EMBO J 9:2685-2692.

Doble BW, Kardami E (1995) Basic fibroblast growth factor stimulates connexin-43 expression and intercellular communication of cardiac fibroblasts. Mol Cell Biochem 143:81-87.

Doble BW, Chen Y, Bosc DG, Litchfield W, Kardami E (1996) Fibroblast growth factor-2 decreases metabolic coupling and stimulates phosphorylation as well as masking of connexin43 epitopes in cardiac myocytes. Circ Res 79:647-658.
Geimonen E, Jiang W, Ali M, Fishman GI, Garfield RE, Andersen J (1996) Activation of protein kinase $\mathrm{C}$ in human uterine smooth muscle induces connexin-43 gene transcription through an AP-1 site in the promoter sequence. J Biol Chem 271:23667-23674.

Ghosh A, Greenberg ME (1995) Distinct roles for bFGF and NT-3 in the regulation of cortical neurogenesis. Neuron 15:89-103.

Giordano S, Sherman L, Lyman W, Morrison R (1992) Multiple molecular weight forms of basic fibroblast growth factor are developmentally regulated in the central nervous system. Dev Biol 152:293-303.

Guthrie SC, Gilula NB (1989) Gap junctional communication and development. Trends Neurosci 12:12-15.

Harfst E, Severs NJ, Green C (1990) Cardiac myocyte gap junctions: evidence for a major connexon protein with an apparent relative molecular mass of 70 000. J Cell Sci 96:591-604.

Kardami E, Stoski RM, Doble BW, Yamamoto T, Hertzberg EL, Nagy JI (1991) Biochemical and ultrastructural evidence for the association of basic fibroblast growth factor with cardiac gap junctions. J Biol Chem 266:19551-19557.

Kumar NM, Gilula NB (1996) The gap junction communication channel. Cell 84:381-388.

Laemmli UK (1970) Cleavage of structural proteins during the assembly of the head of bacteriophage T4. Nature 227:680-685.

Laird DW, Castillo M, Kasprzak L (1995) Gap junction turnover, trafficking, and phosphorylation of connexin43 in Brefeldin A-treated rat mammary tumor cells. J Cell Biol 131:1193-1203.

Lau AF, Kanemitsu MY, Kurata WE, Danesh S, Boynton AL (1992) Epidermal growth factor disrupts gap-junctional communication and induces phosphorylation of connexin43 on serine. Mol Biol Cell 3:865-874.

Lee PL, Johnson DE, Cousens LS, Fried VA, Williams LT (1989) Purification and complementary DNA cloning of a receptor for basic fibroblast growth factor. Science 245:57-60.

Lefebvre DL, Piersanti M, Bai XH, Chen ZQ, Lye SJ (1995) Myometrial transcriptional regulation of the gap junction gene, connexin-43. Reprod Fertil Dev 7:603-611.

Loewenstein WR (1979) Junctional intercellular communication and the control of growth. Biochim Biophys Acta 560:1-65.

LoTurco JJ, Kriegstein AR (1991) Clusters of coupled neuroblasts in embryonic neocortex. Science 252:563-566.

LoTurco JJ, Owens DF, Heath MJS, Davis MBE, Kriegstein AR (1995) GABA and glutamate depolarize cortical progenitor cells and inhibit DNA synthesis. Neuron 15:1287-1298.

Madhukar BV, Oh SY, Chang CC, Wade M, Trosko JE (1989) Altered regulation of intercellular communication by epidermal growth factor, transforming growth factor-beta and peptide hormones in normal human keratinocytes. Carcinogenesis 10:13-20.

Maher PA (1993) Inhibition of the tyrosine kinase activity of the fibroblast growth factor receptor by the methyltransferase inhibitor $5^{\prime}$ methylthioadenosine. J Biol Chem 268:4244-4249.

Makarenkova H, Becker DL, Tickle C, Warner AE (1997) Fibroblast growth factor 4 directs gap junction expression in the mesenchyme of the vertebrate limb bud. J Cell Biol 138:1125-1137.

Maldonado PE, Rose B, Loewenstein WR (1988) Growth factors modulate junctional cell-to-cell communication. J Membr Biol 106:203-210.

McConnell SK (1991) The generation of neuronal diversity in the central nervous system. Annu Rev Neurosci 14:269-300.

McKay RD (1989) The origins of cellular diversity in the mammalian central nervous system. Cell 58:815-821.

Monaghan P, Perusinghe N, Carlile G, Evans WH (1994) Rapid modulation of gap junction expression in mouse mammary gland during pregnancy, lactation and involution. $\mathrm{J}$ Histochem Cytochem 42:931-938.

Monaghan P, Clarke C, Perusinghe NP, Moss DW, Chen XY, Evans WH (1996) Gap junction distribution and connexin expression in human breast. Exp Cell Res 223:29-38.

Musil LS, Cunningham BA, Edelman GM, Goodenough DA (1990) Differential phosphorylation of the gap junction protein connexin-43 in junctional communication-competent and deficient cell lines. J Cell Biol 111:2077-2088.

Nadarajah B,Thomaidou D, Evans WH, Parnavelas JG (1996) Gap junctions in the adult cerebral cortex: regional differences in their distribution and cellular expression of connexins. J Comp Neurol 376:326-342.

Nadarajah B, Jones AM, Evans WH, Parnavelas JG (1997) Differential expression of connexins during neocortical development and neuronal circuit formation. J Neurosci 17:3096-3111. 
Nurcombe V, Ford MD, Wildschut JA, Bartlett PF (1993) Developmental regulation of neural response to FGF-1 and FGF-2 by heparan sulfate proteoglycan. Science 260:103-106.

Pappas IS, Parnavelas JG (1997) Neurotrophins and basic fibroblast growth factor induce the differentiation of calbindin-containing neurons in the cerebral cortex. Exp Neurol 144:302-314.

Pappas IS, Parnavelas JG (1998) Basic fibroblast growth factor promotes the generation and differentiation of calretinin neurons in the cerebral cortex in vitro. Eur J Neurosci 10:1436-1445.

Pepper MS, Meda P (1992) Basic fibroblast growth factor increases junctional communication and connexin 43 expression in microvascular endothelial cells. J Cell Physiol 153:196-205.

Powell PP, Finkelstein SP, Dionne CA, Jaye M, Klagsbrun M (1991) Temporal, differential and regional expression of mRNA for basic fibroblast growth factor in the developing and adult rat brain. Mol Brain Res 11:71-77.
Rakic P (1995) Radial versus tangential migration of neuronal clones in the developing cerebral cortex. Proc Natl Acad Sci USA 92:11323-11327.

Temple S, Davis AA (1994) Isolated rat cortical progenitor cells are maintained in vitro by membrane-associated factors. Development 120:999-1008.

Temple S, Quian X (1995) bFGF, neurotrophins and the control of cortical neurogenesis. Neuron 15:249-252.

Ullrich A, Schlessinger J (1990) Signal transduction by receptors with tyrosine kinase activity. Cell 61:203-212.

Weise B, Janet T, Grothe C (1993) Localization of bFGF and FGFreceptor in the developing nervous system of the embryonic and newborn rat. J Neurosci Res 34:442-453.

Yamamoto T, Kardami E, Nagy JI (1991) Basic fibroblast growth factor in rat brain: localization to glial gap junctions correlates with connexin43 distribution. Brain Res 554:336-343. 